ORNITH
QL
696
P2
T71
1910



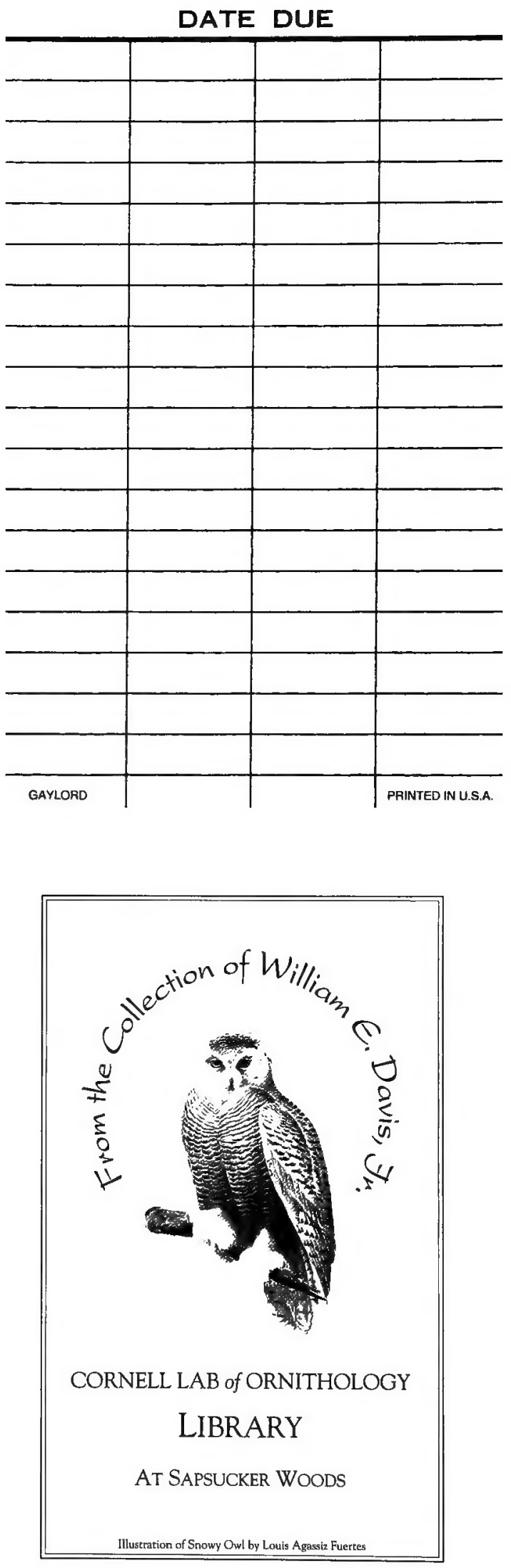
UNIVERSITY OF OALIFORNIA PUELICATIONS

in

ZOOLOGY

Vol. 6, No. $13,9 \mathrm{p} .285-312$

December 28,1910

\section{SIGNIFICANGE OF WHITE MARKINGS}

IN

\section{BIRDS OF THE ORDER PASSERIFORMES}

BY

HENRY CHESTER TRACY

BERKELEY

THE UNVERSITY PRESS 
Toto--The University of Calffornia Publications are ofiered li exchange for the publi. cations of learned societies and institutions, universities and libraries. Complote IIts of Il the publications of the University will be sent upon request. For sample copies list of publications or other information, address the Nhanager of the University Press, Ber eley; Califormie, J. S. A. All matter sent in exchange should bo addressed to the rrehange Department, University Iibrary, Berkeley, California, U. S. A

\section{OLHO FARRASBOWILt IEIPZIS}

Agent for the series in Anicrican Alth aodogy and Ithnology, Classical Philology. Fiducation, Modern Philology, Philosophy, Psychology.

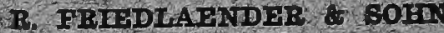 BHBTIN}

Agent for the sertes in Americtan Arch aeology and Bthriology, Botany, Ceology Wathematice, Patholoms, Physiologr, 2hool ogy, and Memolrs.

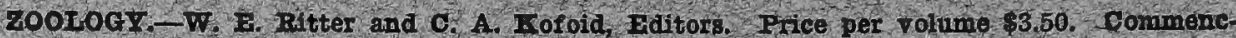
Ing with Volume If, this sories contains Contributions from the Irabotatory of the Maxing Biological Association of Sim Diego.

Cited as Inif Coll, Irbl. 2001

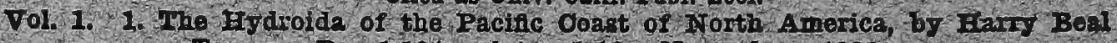
Torrey. Pp, 1-104; plates 1-11. Novembor, 1902.

2. A Case of Physiological Polanization in the Ascidian Ieart, by Frans W. Bancroft and O. O. Esterly. PD. 106-114. Apri, 1903.

3. Fmbryology and Imbryonic Fission in the Genus Grisin by Alice Robertson. Pp, 115-156, plates $12-15$, June, 1903

4. Correlated srotective Devices in some California Salamanders, bs Marion 15. Hubbard, Pp. 167-170, plate 16. November, $1903 . .$.

5. Studies on the geologs, Morphology and Speciology of the Young of some rateropmeista of Westem Worth Amorlez, by Willim F. Ritter and B. M. Davis. PF. 171-210, plates 17-19. Fobmary, 1904.

6. Regeneration and Non-Sexual Reproductor in Sagantia davis, by

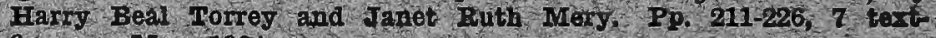
figures. May, 1904

7. The structure and Regeneration of the Polison Glands of Plothodon, by C. O. Esterly. IP, 227-268, plates 20-83. June, 1904.

8. The Distribution of the Sense-organs in Micrescolea elegañ, by John I. Bovard, Pp, 268-286, plates 24-25. Deceruber, 1904

2. Some New Iintinnidae from the Plankton of the San Diego Region, by Charles A. Krofoid. Pp. 287-306, plates 26-28. July, 1906 _... Index, pp: 307-317.

Vol. \&. (Contributions from the Iaboratory of the Marine Biological Aisgociation of San Diego.)

Intzoduction. A General statement of the Ideas and the present Ams and Status of the Marine Biological Association of San Diego, by William 17. Rittex, Director of the Station. Pp, i-zvil. 2 Maps

1. The Ifydraids of the San Diego Region, by Hamp Beal Iorrey ip. 143. 22, text figires: December, 1904.

2. The Ctenophores of the San Diego Rogion, by Harry Beal Forroy. Pp. 45-51, plate 1. December, 1004.

Nos, 1 and 2 in one cover.

8. The Pelagic Iunicata of the San Diego Region, excepting the trarivaces by Wiliam 3. Ritter. Pp. 51-112, plates 2-8, 31 tert-figures Junuars, 1805

4. The Pelagic copepoda of tho San Dlego Reglon, by C. 0. Btterly. Pp. 11 2 233 , 62 tert figures. September, 1905

5. The Hon-encrusting Chilostomataus Bryozon of the West Oorst of Trorth America, by Alice Fóbertson. Tp. 235-822, plates 4-16. Docember, 1905

6. Differentiation in Hyaroid Colonies and the Problem of Benescence, by Harry Beal Torrey. Pp. 282-332, 4 text-figures. December, 1905.

7. The Beliavior of Corymorphe, by Harny Beal Torroy. 20. 338-340, 5 - text-figures.

Nos, 6 and 7 in one corer

8. Dinotlagellata of the San Diogo Region. I. On Heterodininm, J Jow Genus of the Peridinidae, by Charled Atwood Kofold. PD. 341-368, plates 17-19. January, 1906 Index, pp. 369-382.

- Sepply limited; sold only with completo tolumos. 
UNIVERSITY OF CALIFORNIA PUBLICATIONS

IN

ZOOLOGY

Vol. 6, No. 13, pp. 285-312

December 28, 1910

\section{SIGNIFICANCE OF WHITE MARKINGS}

IN

BIRDS OF THE ORDER PASSERIFORMES.*

BY

HENRY CHESTER TRACY.

CONTENTS.

Introduction

Intrinsic Faetors in the Evolution of Color.......................................... 286

White Markings as Visual Clues.................................................................... 289

The Problem Discussed for Birds of the Open........................................ 295

The Problem Discussed for Arboreal Species .......................................... 297

Special Study of the Mniotiltidae......................................................... 305

Sexual Selection as Affecting White Patterns............................................. 308

Directive Markings Outside the Order Passeriformes........................... 309

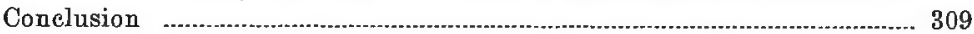

\section{INTRODUCTION.}

The present investigation was undertaken for the purpose of testing the validity of one of the earliest recognized categories of coloration, that of "Directive Markings," in a single order of birds. The term directive is used in the sense given it by Todd (1888) and not that of later writers (Marshall, 1902), who have used the word as expressing a different function of white markings in butterflies' wings_protective through drawing the enemy's attack away from vital parts. As here used it resembles the term recognition markings, and might be regarded as a

* The present paper is the result of work carried on in the Department of Zoology of the University of California as partial fulfillment of the requirements for the master's degree, under the direction of Professor Charles A. Kofoid, to whom the writer is indebted for advice and criticism. $\mathrm{He}$ is also under many obligations to Mr. Joseph Grinnell, Director of the Museum of Vertebrate Zoology, for much information placed at his dsposal. The author also had access to the large collections in the Museum, and was allowed free use of these and of such data on file there as proved pertinent to the problem in hand. 
right in asserting that further evolutionary studies of bird coloration should take their departure from this point. Nevertheless, if this be true, the gap between fundamental bars in feathers and the varied patterns in which white appears in every conceivable combination, often accompanied by intensification of pigment deposits in adjacent plumage, is one which can only be filled by difficult, expensive, and long continued research. In the meantime the discoveries of Thayer (1909) have greatly simplified the explanation from the selective standpoint, while those of Reighard point to an intrinsic tendency toward variety of pattern, needing only immunity such as that afforded by a coral reef, to develop colors and contrast that are neither adaptive nor due to sexual selection, and for which the physiological elements of nutrition, temperature, etc., do not account. Thus it is probable that the production of bars and stripes in feathers, and the rate of pigment deposit, are but secondary processes in a larger scheme. They may themselves be dependent on selective agencies which, if they exist at all, operate upon the whole organism.

If we were concerned here with the problem of bird coloration in general, we might linger upon examples of an apparent physiological basis for dark coloration, such as that of most species of Corvidae; these are largely omnivorous feeders, active and of exuberant vigor. But we should certainly be wrong if we failed to take account of the great degree of immunity which these birds enjoy from the attacks of raptorial birds, because of their size and aggressiveness. It is doubtful whether a seedeating bird of delicate flesh and harmless disposition could have been permitted to develop such a black plumage as that of the raven, even had the physiological excuse for pigment excretion been as great in its case. Some other way would have been found, we may reasonably say, for the excretion of melanin, or else that type of bird would have become extinct for lack of protective coloration.

Similar difficulties involve such special varieties of the physiological explanation of color patterns as are connected with color distribution on the breast, crown, rump, etc., of birds, regarded as centers of high or of deficient circulation. A study 
of any series of birds ranging through half a dozen families will give quite contradictory results. The crown will be fbund white on some, black on others; the breast usually light colored, but sometimes with a spot or chain of spots, or the throat spotted and the breast plain; and the rump white in some, heavily pigmented in others. Only patient ingenuity could long persist in seeking evidence for the correlation of pigmented areas with regions of fuller circulation; and the seeker for such evidence must shut his eyes to the patent fact that to produce a monochrome plumage such as that of the Leconte thrasher the dermal circulation must be uniform over the entire surface of the body; the existence of the theory would seem to demand the denial of such a condition.

Cunningham's suggestion (1900, p. 109) of a local stimulus incident to the elevation of plumes, etc., in courtship, is useful in accounting for the special development of certain epidermal features, but it sheds no light on the cause of intensification of color in the breeding male, in the plumage as a whole. The vigor theory attempts to do this, but leaves untouched a large number of instances in which there exists no sexual dimorphism in coloration, and still others in whish the female takes over not only the color character, but also the courting antics of the male, leaving him the responsibility for incubation, as is the case in the knot (Tringa canutus).

The other class of intrinsic factors in color evolution grouped under the general term heredity, is one which this paper will merely recognize as existing, a potent but little understood influence. If it can be shown that white markings do not occur indiseriminately on birds of all habits and environments, but are associated with similar habits and ranges among birds not otherwise closely allied, it will be clear that they cannot be regarded solely as evidences of the manifestation of hereditary tendencies, but may fairly be attributed, at least in part, to selective influences.

Whatever the original cause of pigmentation or absence of pigment and its replacement by structural colors, and whatever the mode of evolution of such colors and combinations, the assumption of a principle of natural selection everywhere efficient 
though sometimes passive, is justified by the facts as to the distribution of white patterns in passeriform birds of the United States.

\section{WHITE MARKINGS AS VISUAL CLUES.}

Coloration in birds, whatever its cause or the mechanism of its production, is conceded to be adaptive; it responds to their needs, forms a part of their life adjustments.

Concealment from its enemies is not the only need in a bird's life, not the only adjustment that affects color-patterns. The bird also needs to be made known to other individuals of its kind, and to other species associated with it; and this need has certainly been met. Just how it has been met depends upon the bird's manner of life, and upon its chosen habitat; this much we know. Without entering upon any disputed phase of the subject, we may state at the outset that the need exists and has been met, if not by special provision in coloration, at least by peculiarities of form and manner, or by qualities of voice.

The vital importance to a bird of seeing and being seen by its companions, hardly finds a parallel among the lower vertebrates; certainly not among most fishes, though a school of fishes bears a superficial resemblance to a flock of birds. Neither in organization nor in instinct does the one approach the high development of the other. A comparison of the brain of a perch with that of a pigeon shows the remarkable superiority of the latter in respect to cerebral development. The phenomena of the associations of a bird's life, the well-known facts of mutual independence in feeding, nesting and migration among nearly all of the class Aves, indicate the degree to which individualism has been subordinated, and coöperation of a certain kind developed.

There are, however, great differences within the class. If we are to make any comparison between these and the lower vertebrates, let it be between gregarious sea-birds and fishes, not between oscines and herring. Delicate life-adjustments are to be found among the higher genera of the perching birds that are missing from the more primitive divers or long-winged swimmers, as well as from fishes. The number and variety of perils 
that daily surround our smaller land-birds, and the extent to which these may be diminished by the birds' keeping in touch with one another, point to the need of something more than concealing coloration, and admit of special adaptions that shall act in harmony with it and yet serve to reveal the bird to its kind.

Notwithstanding this distinction there will be some who fail to find in the life-relations of the Passeriformes anything to occasion the development of marks whose main function shall be that of revealing the birds to each other. Thayer (1900), exposing the weakness of the "banner-mark theory," indirectly implicates all theories of directive coloration, as well as that of warning colors, and has since made them the object of special attack (A. H. Thayer, 1909). The ground for his criticism-and it is a good one-is that birds, in order to profit by such aids as signs and signals, or at least to need them, must be less acute than human observers, who easily recognize species of birds by slight hints, such as are afforded by silhouette, by mode of flight, by mannerisms of one sort or another, rather than by special marks. This is so true that it must and does discredit the crude interpretations such as the title "banner-mark" suggests. We must distinguish between hypothetical functions, the creation of fancy, and a series of well-defined stripes, bars, or checks, which may be interpreted by any one of at least three categories, of which that of "concealing coloration" is only one.

Starting out with a presumption in favor of some form of revealing clues among the higher land-birds, and eliminating a terminology which has been misleading, it remains for us to determine, if possible, what these clues are, and whether color features form a part of them; if so, how this harmonizes with the function of the same or similar color features as concealing.

How do the birds of our woods and fields actually keep track of one another? Obviously to a great extent by vocal sounds which they utter frequently when moving about in the foliage, or in unison when leaving a feeding ground as a flock; by callnotes, when moving in pairs or companies; by location notes, when separated and seeking to come together. No one doubts the existence of such vocal clues or their vital necessity to birds belonging to the order under discussion. 
There are birds that appear to depend almost entirely upon directive calls for keeping together; they have become habituated to feeding in close and uninterrupted cover where they see other birds only at close range, or very seldom at any great distance. Obviously they must keep within hearing, or be lost to their companions. Sound-clues are sufficient in their case. This is true of the bush-tit (Psaltriparus minimus californicus), some warblers, and nearly all the wrens. These are birds of plain colors, for the most part, and without white patterns of any sort.

Among arboreal birds of open feeding range that are constantly exposed to view, different conditions obtain. Call-notes are used, but glimpses of other birds in flight may be just as useful for purposes of direction, since such glimpses are frequently to be had. Sight plays a part of corresponding importance in the economy of bird-movement-to some extent replaces sound as a means of recognition.

As there is in the general coloration of open-ranging birds no response to the need of some rapid and easy means of recognition, and as the special color patterns that have heretofore been regarded as serving that purpose are now being claimed as a part of "concealing coloration"' (A. H. Thayer, 1909), it might appear that the category of directive markings is soon to lose its status altogether. But general coloration is seen to be normally protective, for birds that need protection; and as for the special patterns, even a satisfactory demonstration of their "obliterative" effect does not warrant the conclusion that such is solely or mainly their effect in all cases.

For a discussion of the "disruptive effect of color patterns" the reader is referred to G. H. Thayer, 1909, pp. 77-79, and to A. H. Thayer, 1909, pp. 562 et seq. The evidence here offered of their value as revealing characters, múst not be regarded as contradicting anything but the application of the "concealing" principle to birds in fight.

During the month of February the writer had under observation a flock of fifteen meadowlarks (Sturnella neglecta), which foraged in vacant lots and fields within the city limits of Berkeley. They were well spaced while feeding, and when disturbed some 
would fly across a road into the neighboring field, where they would presently be followed by others. Their white tail-borders were often conspicuous during the entire flight of the birds, the tail remaining partly spread. As the meadowlarks on being flushed rose to the height of a man's head or higher, they must have seen the retreating forms from a similar view-point, i.e., against a dark background. They would not commonly see them against the sky. For the birds themselves, white tail-borders would serve no purpose if not a directive one. Common observation does not seem to be at fault here, nor the term "white . guides" ill-chosen.

It will be seen that the common assumption to the effect that white upon an object makes it conspicuous is well grounded in this case, for the reason that there is nothing corresponding to it in the usual background; further, because it does not in the least efface the outlines of the bird's contour, and finally because the bird is in motion at the time when the marking is displayed. We take note, therefore, of the distinction between a flightexposed marking and one that appears at its full value when the bird is at rest. The former acquires added conspicuousness from the fact that a moving object fixes and holds the attention, indeed a white object moving across a dull background is the best mechanism that can well be devised for signalling at long distances.

Mr. A. H. Thayer, in the article to which we have just referred, indicates a supposed correlation between white rearmarkings and the habit of nesting on the ground and flying from the nest when disturbed, stating that the markings are absent from birds that habitually run from it to escape a furred enemy. This would point to an obliterative function in the rearmark, which shows white against the sky as seen from the level of a quadruped. This statement and conclusion seem to have been hastily made, for they apply only in the case of water birds such as rails, coots and gallinules which the author of the statement had in mind. The horned lark (Otocoris alpestris, all subspecies), the meadowlark (Sturnella magna and $S$. neglecta), and the vesper sparrow (Pooecetes gramineus), are among the 
rear-marked birds that run from the nest, habitually, when disturbed.

In the foregoing paragraphs, the evidence for the revealing function of white rear-markings exposed in flight has been given as common observation, supplemented by psychological analysis of the facts; and the supposed instance of a concealing function in the case of certain birds has been shown to be quite inconclusive as regards perching birds. These considerations alone would point strongly to the other interpretation of the markings as advanced by Todd (1888), and rather generally accepted since. They are not, however, the only.ones bearing on the question.

In giving recognition to the theory of directive markings of this type Wallace (1889, p. 222) alluded to their prevalent occurrence among flocking birds, as strengthening the theory, since it was just here that they would be of the greatest use. $\mathrm{He}$ did not, however, test the facts regarding such occurrence, or inquire into the question of a significant absence of white markings among non-flocking birds; nor has anyone else done so, heretofore. It is a test that is easily made by segregating all the birds bearing the white rear-marks, and making an inventory of those that remain. In order to judge of the significance of the resulting division it is necessary to know to what extent the birds thus arbitrarily separated differ in habits, especially as regards flocking; and this is not as easy as might be supposed, among the perching birds.

The accompanying list gives all the species of open-ground passeriform birds native to North America. Although the white tail-borders occur also on a few arboreal birds, these may be regarded as coming in the class of "top-patterns," which will be taken up in connection with birds of the forests and thickets. 


\section{PASSERIFORM BIRDS OF THE OPEN.}

WITH CONCEALED WHTTE.

$\begin{array}{lc}\text { ICTERIDAE } & \text { Junco hyemalis, all subsp. } \\ \text { Sturnella magna } & \text { Junco aileni } \\ \text { Sturnella neglecta } & \text { Junco phaeonotus, } 3 \text { subsp. } \\ \text { ALAUDIDAE } & \text { Junco bairdi } \\ \text { Otocoris alpestris, all subsp. } & \text { Junco insularis } \\ \text { Alauda arvensis } & \text { MoTACrLIADAE } \\ \text { FRINGILLIDAE } & \text { Anthus pratensis } \\ \text { Calcarius lapponicus } & \text { Anthus spraguei } \\ \text { Calcarius pictus } & \text { Anthus cervinus } \\ \text { Calcarius ornatus } & \text { Anthus - rubescens } \\ \text { Rhyncophanes mecowni } & \text { Budytes flavus alascensis } \\ \text { Pletrophenax nivalis, all subsp. } & \text { Motacilla alba } \\ \text { Plectrophenax hyperboreus } & \text { Motacilla ocularis } \\ \text { Calamospiza melanocorys } & \text { TROGLODXTIDAE } \\ \text { Chondestes grammacus subsp. } & \text { Heleodytes brunneicapillus } \\ \text { Pooecetes gramineus, 2 subsp. } & \text { Oroscoptes montanus }\end{array}$

\section{WITHOUT CONCEALED WHITE.}

$\begin{array}{ll}\text { FRINGILLIDAE } & \text { Passerherbulus caudacutus } \\ \text { Leucosticte atrata } & \text { Passerherbulus nelsoni } \\ \text { Leucosticte australis } & \text { Passerherbulus maritimus, } \\ \text { Lencosticte tephrocotis } & 2 \text { subsp. } \\ \text { Leucosticte griseonucha } & \text { Peucaea aestivalis botterii } \\ \text { Passerculus bairdi } & \text { Peucaea mexicana } \\ \text { Passerculus princeps } & \text { Peucaea cassini } \\ \text { Passerculus sandwichensis, } & \text { Aimophila ruficeps, and subsp. } \\ 3 \text { subsp. } & \text { Aimophila carpalis } \\ \text { Passerculus beldingi } & \text { Spizella. passerina } \\ \text { Passerculus rostratus } & \text { Spizella p. arizonae } \\ \text { Ammodramus savannarum austra- } & \text { Spizella breweri } \\ \text { lis } & \text { Spizella pallida } \\ \text { Ammodramus s. bimaculatus } & \text { Spizella atrogularis } \\ \text { Passerherbulus henslowi } & \text { Spizella pusilla, and subsp. } \\ \text { Passerherbulus lecontei } & \end{array}$

\section{WITH WHITE IN NUPTIAL PLUMAGE.}

ICTERIDAE

Dolichonyx orizivorus

FAINTLY MARKED WITH WHITE.

Amphispiza bilineata

Amphispiza belli

Amphispiza nevadensis 


\section{THE PROBLEM DISCUSSED FOR BIRDS OF THE OPEN.}

The list shows five families that carry white markings, as against two families that do not. Of the twenty-six species or subspecies that carry them, all but three are to be classed as flocking birds; and even these are unquestionably gregarious to a marked extent. They may follow each other serially from place to place, as the cactus wren (Heleodytes brunneicapillus) and the sage thrasher (Oroscoptes montanus), or they may flock for a limited season, as the vesper sparrow (Pooecetes gramineus). The list contains the most perfect types of flocking birds in the whole order, such as the meadow pipits of the genus Anthus, and the horned larks (Otocoris alpestris), the lark sparrows (Chondestes grammacus), and all the juncos. Taken as a whole the white-marked group is unquestionably a flocking series. The bearing of this on the problem of white markings in birds is made clear by a comparison with the second list in which all but the species of two genera, Leucosticte and Dolichonyx, are seen to be of a non-flocking, skulking type, exemplified by the grasshopper and Savannah sparrows. Of these two exceptional genera the leucostictes are birds of the Boreal Zone exclusively, feeding on wind-blown insects at high altitudes; themselves conspicuous through their dark coloration and, by virtue of their AlpineArctic habitat, escaping most of the birds of prey. In short, they are of an environment altogether different from that commonly referred to as "open ground" in the sense of prairie and plains, and may be eliminated from the comparison. Dolichonyx, the bobolink, on the other hand, is a bird in its southern habitats palustrine, and only in its breeding range a bird of the meadows, where it displays the qualities of the second group, and is, in the case of the female, like them unmarked. The coloration of the male in breeding plumage evidently corresponds to that of the marsh blackbirds, to which it is closely allied. Our second list, then, if it be found to contain no flocking birds but the two just mentioned, is a striking proof of the absence of white markings in birds of the open ground that do not flock.

For an interesting exhibition of correspondence between habit and coloration, we turn to the grasshopper and Sandwich spar- 
rows (Ammodramus, Passerculus). To quote a pertinent description: "Among the many inconspicuous, plain, little striped-backed sparrows of the Western United States, alaudinus is one of the commonest, plainest, and most inconspicuous Anywhere in the meadows, prairie grass or weed patches, one may dart out from under your feet, zig-zag over the grass tops for a little way, and drop into the grass, hopelessly lost until he is again forced to take wing. At a distance you see and hear the birds giving their plain little song from the top of a tall weed or fence stake, but on nearer approach they drop into the grass and are lost." This characteristic is here emphasized because in all of the species mentioned as unmarked birds we shall find this or similar traits having a like bearing on our problem, while in all of them the typical flocking habit is lacking. The latter may be replaced by what might be termed a spurious form of flocking. As an instance: the rufous-crowned sparrow (Aimophila ruficeps), common on the Berkeley hills, may be surprised feeding in open patches when it at once takes to brushy cover far from which it does not stray; and when traveling moves in loose bunches of scattered individuals flitting from bush to bush unostentatiously.

Field ornithologists will observe, however, that others of the birds here mentioned are in some sense gregarious and gather at certain seasons for migratory or other movements. We have, however, evidence to the effect that such movements are sometimes, if not always, essentially different from typical flocking. Two western sparrows from the arid region are frequently seen in considerable numbers moving from their southerly winter range to a summer habitat to the northward. To the casual observer they might appear to be "flocking birds." A quotation from a memorandum made by Mr. Grinnell during the recent Museum Expedition to the region along the Colorado River, will show the error of such conclusions.

"Both Spizella breweri and S. socialis are now abundant on the desert in migrating flocks, not flocks, however, in the sense that pipits flock, but scattering companies. Each individual in a company moves wholly independently of any other; and they do not move en masse when alarmed, but helter-skelter in different 
directions around and through bushes without call-notes. The helter-skelter disappearance of the flock certainly puzzles me and leaves me wondering where any one of the birds may be relocated. The eye gets no single permanent impression."

The behavior here cited is found when analyzed to be the exact opposite of what occurs in a typical foraging flock of birds having white rear-markings. In a flock of pipits the birds do not move independently, as a rule, in changing feeding grounds; they move in a body when alarmed, in one general direction, with great uniformity; not through bushes, always with callnotes, thus using every reasonable means of keeping the flock together. Under stress of alarm, growing darkness, or accidental scattering through considerable distance, the bright moving rearmarks must at least be of appreciable value to the bird in keeping others of the flock in sight. Whether or not that is the main reason for their existence is, of course, open to question.

\section{THE PROBLEM DISCUSSED FOR ARBOREAL SPECIES.}

We have been considering up to this point only the white markings characteristic of birds of the open. Among arboreal species the problem becomes more complicated both as to variety and distribution of the patterns and their possible significance. A form of "top-white" which can be shown to have the effect of making the wearer conspicuous is the basal patch of white upon flight feathers, usually the bird's primaries. . It need not have this effect, however, when regarded as a fixed pattern against a foliage background. The latter gives it a disruptive value, as Thayer (1909) has shown for similar designs. In order to test the concealing values of this particular wing marking I mounted the green-backed goldfinch (Astragalinus psaltria hesperophilus) and the black-headed grosbeak (Zamelodia melanocephala) with spread wings and photographed them against sunlit foliage and backgrounds of leaves with spaces of sky showing through them. The birds were difficult to find in the resulting prints. Undoubtedly the photographs by their lack of relief exaggerated the concealing effect; yet that there is such an effect, in general, it is safe to admit. 
When, however, the bird takes wing a wholly different principle comes into play. Suppose it be the goldfinch that has left its perch. What we actually see is a pair of wings opened and closed, alternately revealing and concealing a pattern which finds no background to blend with, because it consists of intermittent flashes of white, not haphazard like the ruffling of leaves, but rhythmical, emphasizing the essential features of the flying bird. This is not speculation but a description of facts-it is what one sees in the field. Those who are unfamiliar with the bird named may recall a similar flight-effect in the black-throated blue warbler (Dendroica caerulescens), and even more striking patterns in the common shrike (Lanius ludovicianus), the mockingbird (Mimus polyglottos) and the "black mocker" (Phainopepla nitens). Concealed wing patterns are not the only ones that become conspicuous in flight. Obviously any white pattern located on primaries, secondaries, tertials, or wing coverts, will be expanded to the greatest extent during the motions of flight. It happens that even the comparatively obscure wing bars of the lazuli bunting (Passerina amoena) are easily distinguished as white bands on the flying bird. The white of scapular feathers, as in the magpie, is emphasized in the same way. Tail blotches on some warblers reveal their whereabouts as they flit from twig to twig, rather than conceal them. I have not, therefore, attempted to distinguish various classes of top markings among arboreal birds with a view to finding special functions for each. It is precisely such attempts that have discredited theories of the functions of these markings. Arbitrary distinctions do not occur in nature.

In order to give the reader an opportunity to review the entire series of white-patterned birds and to compare it with the complete series of those that lack top-white, I have prepared the accompanying lists. One family, the Mniotiltidae, has been reserved for more detailed study, and is given in a separate list. The ground-frequenting birds of the open have already been given. These lists, therefore, are fully representative of arboreal perching birds of the temperate zone, and include all species of the order Passeriformes regularly found in the United States. 


\section{PASSERIFORM BIRDS OF ARBOREAL HABIT.}

\section{A. BIRDS WITH WHITE WING OR TAIL MARKINGS.}

\section{Fringillidae}

Hesperiphona vespertina

Pinicola enucleator leucura

Loxia leucoptera

Astragalinus tristis

Astragalinus psaltria

Astragalinus psaltria hesperophilus

Zamelodia melanocephala

Zamelodia ludoviciana

Passerina amoena

Sporophila morelleti sharpei

Spizella monticola

Pipilo erythrophthalmus

Pipilo maculatus

LAANIIDAE

Lanius borealis

Lanius ludovicianus

\section{VIREONIDAE}

Lanivireo solitarius

Vireo belli

Vireo huttoni

\section{ICTERIDAE}

Icterus nelsoni

Icterus melanocephalus auduboni

Ioterus cucullatus sennetti

Ioterus bullocki

Icterus parisorum

Xanthocephalus xanthocephalus

Troglodytidae

Mimus polyglottos
TuRdidat

Myadestes townsendi

Planesticus migratorius

Planesticus confinis

\section{SitTidae}

Sitta canadensis

Sitta pygmaea

\section{Corvidae}

Nucifraga columbiana

Pica pica hudsonia

Pica nuttalli

Cyanocitta cristata

Tyrannidae

Muscivora forficata

Tyrannus tyrannus

Tyrannus verticalis

Myiarchus cinerascens

Myiarohus magister

Sayornis nigricans

\section{StLvitdae}

Polioptila caerulea

Polioptila californica

Polioptila plumbea

HIRUNDINIDAE

Hirundo erythrogaster

Tachycineta thalassina

\section{BOMBYCILLIDAE}

Bombycilla garrula

Phainopepla nitens

Paridae

Penthestes atricapillus

B. BIRDS WITHOUT WHITE WING OR TAIL MARKINGS.

TURDIDAE

Ixoreus naevius

Hylocichla mustelina

Hylocichla fuscescens

Hylocichla guttata

Hylocichla ustulata

Hylocichla aliciae

Sialia sialis

Sialia mexicana
Sialia currucoides

Cyanosylvia suecica robusta

Cinclidae

Cinclus mexicanus unicolor

SYLVIIDAE

Acanthopneuste borealis

Regulus calendrula

Regulus satrapa 
Chamaeidae

Chamaea fasciata

Paridae

Baeolophus bicolor

Baeolophus inornatus

Baeolophus atricristatus

Baeolophus wollweberi

Penthestes atricapillus

Penthestes carolinensis

Penthestes sclateri

Penthestes gambeli

Penthestes rufescens

Penthestes hudsonicus

Penthestes cinctus alascensis

Psaltriparus minimus

Psaltriparus melanotis lloydi Auriparus flaviceps

SitTIDAE

Sitta carolinensis

Certhindae

Certhia familiaris

TROGLOdY TIDAE

Dumetella carolinensis

Toxostoma bendirei

Toxostoma redivivum

Toxostoma lecontei

Toxostoma crissale

Toxostoma cinereum

Toxostoma longirostre

Toxostoma rufum

Toxostoma curvirostre

Salpinctes obsoletus

Salpinctes guadalupensis

Catherpes mexicanus

Thryothorus ludovicianus

Spiza americana

Arremonops rufivirgata

Guiraca caerulea

Passerina cyanea

Passerina versicolor

Passerina ciris

Pyrrhuloxia sinuata

Pipilo fusous

Pipilo orissalis senicula

Oreospiza chlorura

TANGARIDAE

Piranga ludoviciana
Piranga erythromelas

Piranga hepatica

Piranga rubra

ICTERIDAE

Molothrus ater

Tangavius aeneus involucratus

Agelaius phoeniceus

Agelaius gubernator californicus

Agelaius tricolor

Euphagus carolinus

Quiscalus quiscula

Quiscalus major macrourus

Corvidae

Cyanocitta stelleri

Aphelocoma woodhousei

Aphelocoma cyanotis

Aphelocoma californica

Aphelocoma texana

Aphelocama sieberi

Aphelocoma insularis

Xanthoura luxuosa glaucescens

Perisoreus canadensis

Perisorens obscurus

- Corvus corax

Corvus cryptoleucus

Corvus brachyrhynchos

\section{TYRANNIDAE}

Tyrannus melancholicus couchi

Tyrannus vociferans

Pitangus sulphuratus derbianu:

Myiodynastes luteiventris

Myiarchus crinitus

Myiarchus lawrencei olivascens

Sayornis phoebe

Sayornis saya

Nuttallornis borealis

Myiochanes pertinax pallidiventris

Myiochanes virens

Myiochanes richardsoni

Thryomanes bewicki

Thryomanes leucophrys

Thryomanes brevicauda

Troglodytes aedon

Troglodytes parkmani

Nannus hiemalis

Telmatodytes palustris

Cistothorus stellaris 


FRINGILLIDAE
Pyrrhula cassini
Carpodacus purpureus
Carpodacus cassini
Carpodacus mexicanus frontalis,
and other subsp.
Carpodacus amplus
Loxia curvirostra
Acanthis linaria
Acanthis hornemanni
Spinus pinus
Astragalinus lawrencei
Cardinalis cardinalis
Melospiza melodia
Melospiza georgiana
Melospiza lincolni
Zonotrichia albicollis
Zonotrichia leucophrys
Zonotrichia coronata
Zonotrichia querula
Passerella iliaca
Empidonax diffcilis
Empidonax flaviventris
Empidonax trailli
Empidonax minimus

Empidonax hammondi

Empidonax wrighti

Empidonax virescens

Empidonax griseus

Empidonax fulvifrons

Pyrocephalus rubineus mexicanus

Camptostoma imberbe

Hirundinidat

Progne chalybea

Progne subis

Progne oryptoleuca

Iridoprocne bicolor

Riparia riparia

BOMBYCILLIDAE

Bombycilla cedrorum

VIREONIDAE

Vireosylva olivacea

Tireosylva philadelphica

Vireosylva gilva

Lanivireo flavifrons

Vireo atricapillus

Vireo griseus

Vireo vicinior

The facts as to the distribution of white markings among birds of the various local associations may be gathered from a study of the first list. It also affords a basis for finding any agreement of physical or temperamental characters among birds so marked, or the occurrence of habits that may have a bearing on their coloration. A similar purpose is served by the second list -with this drawback : it includes a number of color features that may be of a value similar to that of white patterns, and even more revealing. Accordingly we need not be surprised if we find among species bearing such features, for example, nearly all the crows and blackbirds, the habits and distribution that are characteristic of white-marked birds.

There is, moreover, a correspondence, especially among the unmarked groups, that appears to be due primarily to intrinsic influences producing family characters; like all color characters these are too inconstant for the systematist to utilize. Still, in some cases they suggest a persistence of some ancestral type dominating extrinsic influences. Such a correspondence is seen 
in the family of wrens which an amateur can usually recognize by noting the superficial color pattern. A similar tendency appears in the vireos and also in the flycatchers. If, therefore, we find white patterns conspicuously lacking among Troglodytidae, Vireonidae and Tyrannidae, we are bound to consider whether or not this may be partly due to the stability of a type (intrinsic influence) or to selective influences alone. The occurrence of a perfect adaptation at variance with the type in the bleached, sand-colored monochrome of the Leconte thrasher (Toxostoma lecontei) indicates that the Troglodytidae may not be exempt from the strict enforcement of the principles of adaptive coloration, where the conditions of their life demand it.

There are some relative differences among birds that might conceivably enter into the explanation of correspondences in color, but apparently do not to an appreciable extent. Size is one of these. The only way in which it appears to affect coloration is by affording immunity from enemies. Size combined with vigor and aggressiveness opens the way for conspicuous coloration. But the need of concealment on the part of the aggressor neutralizes the effect of this immunity in most cases. The raven is one of the exceptions within the order of perchers, and the condor, Egyptian vulture, and turkey buzzard, outside it. These are birds that need no concealment for aggression, but profit by a conspicuousness that makes them recognizable to each other at great distances.

As for warning coloration, there seems no reason for believing that it occurs among perching birds. Were the principle thoroughly established we might be justified in regarding the magpie as an instance; but since other functions may readily be assigned to the contrasts in its plumage, and since these are not necessarily utilitarian, as the bird is largely "immune," the whole hypothesis is negligible for the birds under discussion.

Temperamental differences form another set of elements to be considered. A search for correspondences in this direction shows at least a few well attested instances of boldness of disposition accompanying the supposed conspicuousness of plumage. Such are the kingbird (Tyrannus tyraninus), the scissor-tailed flycatcher (Muscivora forficata), the mockingbird (Mimus poly- 
glottos), the magpie (Pica hudsonia), and the shrike (Lanius borealis). These are interesting cases, but little can be inferred from them as to the significance of white markings in the group at large.

It is in the correlation of special color features with special feeding and breeding ranges that we get the first clear indication of a large underlying principle determining which birds shall possess the white pattern and which shall not. The top-marked finches are seen to be birds of open woods mainly, largely of roving disposition and wide feeding range. Unmarked species of the family are mainly birds of low zones and narrower feeding beat. Only two of the first list are characteristically low rangers and given to covert-seeking: these are our eastern and western white-marked towhees (Pipilo erythrophthalmus and P. maculatus). On the other hand nearly all of the second list are either confined to close foliage of medium height, or belong to such associations as the rank growth of humid regions, the dark borders of shady swamps, or thickets of the chaparral belt. They are the thrushes, painted in monochrome above; warblers, lacking. top-patterns; wrens with their finely barred color scheme; flycatchers with dull olivaceous or other uniform shadings. These are correspondences that surely have significance, and require for their interpretation something more than the older theories of coloration could offer.

Finding such good illustrations of the disruptive effect of white or bright patterns among animals and birds, the authors of "Concealing Coloration in the Animal Kingdom" (Gerald and A. H. Thayer, 1909), have come to believe that no other explanation is needed to account for the presence of top-white in birds that show themselves against the sky, than natural selection working through this means. Their belief accords with the conditions just cited. It does not, however, take account of the fact already mentioned that markings often become conspicuous during the flight of the bird, nor does it take note of the correlation that has been shown to exist among open-ground birds, of flight-revealed markings with the flocking habit - a condition which we shall also find largely present among the arboreal birds. In the use of these lists of birds to determine the latter point, 
the very arbitrariness of the grouping tends to be misleading. A list of all perching birds that have color features tending to conspicuousness in flight (whether white or some other colon?, would correspond much more nearly to.a complete list of the flocking birds. It would include the gregarious species of the family Icteridae which mainly lack white patterns. It would include the pine siskin (Spinus pinus) which has yellow wing markings instead of white. Yet, even as it stands, the list is very suggestive. When we consider the value to all birds ranging in the open foliage of instant recognition at a distance, and sightclues for the purpose of keeping together, we shall not easily believe that wing and tail white are solely features of concealing coloration. Their revealing function during flight is entirely in harmony with their concealing functions when at rest.

An apt illustration of this harmony of functions is found in the following description of the western evening grosbeak (Bailey, 1902, p. 308):

"On a Sierra grade we have passed a flock busily gathering wild cherries in a bush beside the road, and when camped under the firs of Mt. Shasta have had wandering bands stop for a drink from the camp brook, delighting us by their striking yellow and white plumage. Although they are so highly colored and in flight their white wing patches make such prominent directive marks, this very yellow and white coloration often becomes positively protective. While watching the birds on Mt. Shasta one day, I was struck by the conspicuousness of one that flew across an open space. As it lit on a dead stub whose silvery branches were touched with yellow lichen, to my amazement it simply vanished. Its peculiar greenish yellow toned in perfectly with the greenish yellow of the lichen."

It is of interest to note that the above observation was made before the disruptive effect of white patterns had been demonstrated by Thayer (1909), or the theory of their directive function seriously questioned. There could be no better instance than the one cited, of a double office performed by a single color feature-revealing in flight, concealing when in repose. Precisely this relation, I believe, exists through the group as a whole 


\section{SPECIAL STUDY OF THE MNIOTILTIDAE}

For a more minute study of the relation of white color marks to a bird's habitual range I have chosen the American wood warblers. Not only are the members of this family very well distributed among the more or less well defined strata of local vegetation, but, unlike the Sylviidae or old world warblers, they show the highest degree of specialization both in regard to variety of pigments and to white patterns. It seemed worth while, therefore, to investigate the actual distribution of the species in the three categories of high or open foliage, medium, and low or close coverts. The results of such a study are embodied in the following table in which the mean height of the bird's occurrence has been compared with that of its average nesting site as recorded by numerous observers, and its feeding beat gauged with some accuracy. While it has not always been possible to distinguish clear lines of demarkation, on the whole there is a surprising agreement among writers who allude to the feeding levels of the warblers.

WARBLERS WITH WHITE WING OR TAП MARKINGS.

Of Highest Range.

Vermivora bachmani

Compsothlypis americana

Compsothlypis a. usneae

Compsothlypis pitiayumi nigrilora

Peucedramus olivaceus

Dendroica magnolia

Dendroica tigrina

Dendroica auduboni

Dendroica nigrescens

Dendroica virens

Mniotilta varia

Protonotaria citrea

Vermivora chrysoptera

Vermivora pinus

Dendroica coronata

Dendroica caerulescens

Dendroica pensylvanica
Level of Nest.

$1^{\prime}-3^{\prime}$

$8^{\prime}+$

$8^{\prime}+$

$8^{\prime}+$

$30^{\prime}-50^{\prime}$

$3^{\prime}+$

$3^{\prime}+$

$4^{\prime}-50^{\prime}$

$5^{\prime}-52^{\prime}$

$3^{\prime}-40^{\prime}$

Of Intermediate Range.

$\begin{array}{rlr}\text { ground } & \text { Dendroica kirtlandi } & \text { ground } \\ 5^{\prime}-25^{\prime} & \text { Dendroica discolor } & 1^{\prime}-12^{\prime} \\ \text { ground } & \text { Wilsonia citrina } & 1^{\prime}-5^{\prime} \\ \text { ground } & \text { Cardellina rubrifrons } & \text { ground } \\ 4^{\prime}-20^{\prime} & \text { Setophaga picta } & \text { ground }\end{array}$

OF LOWEST RaNGE.

1'-3' Dendroica palmarum $2^{\prime}$ av.
Level of Nest.

$15^{\prime}$ av.

$2^{\prime}-45^{\prime}$

$40^{\prime}-70^{\prime}$

$20^{\prime}-84^{\prime}$

$20^{\prime}-90^{\prime}$

$50^{\prime}-60^{\prime}$

$15^{\prime}-20^{\prime}$

$1^{\prime}-10^{\prime}$

$8^{\prime}-80^{\prime}$

grounil 


\section{WARBLERS WITHOUT WHITE MARKINGS.}

Of Intermediate Range.

Vermivora peregrina Vermivora celata celata Vermivora c. lutescens Vermivora c. sordida Fermivora rubricapilla Oporornis philadelphia

Helinaia swainsoni Helmitheros vermivorus Vermivora virginiae Vermivora luciae Seiurus aurocapillus Seiurus motacilla Seiurus noveboracensis
Level of Nest. ground ground ground $2^{\prime}-8^{\prime}$ ground $6^{\prime}-20^{\prime}$

\section{Of Lowest Range.}

$\begin{aligned} \text { ground } & \text { Oporornis formosa } \\ \text { ground } & \text { Oporornis agilis } \\ \text { ground } & \text { Geothlypis trichas } \\ 2^{\prime}-6^{\prime} & \text { Geothlypis t. occidentalis } \\ \text { ground } & \text { Tcteria virens } \\ \text { ground } & \text { Wilsonia pusilla } \\ \text { ground } & \end{aligned}$

Level of Nest. $6^{\prime \prime}-4^{\prime}$ $3^{\prime}-5^{\prime}$ ground $2^{\prime}-30^{\prime}$ $3^{\prime}-25^{\prime}$

ground ground ground $6^{\prime \prime}-5^{\prime}$ $1^{\prime}-5^{\prime}$ ground

Of the fifty-seven warblers here treated, thirty-three have well-defined white top-patterns. Of these, twenty are high rangers, a number of them emphasizing their preference by choosing a nesting site at the extraordinary level of seventy, eighty, or even ninety feet from the ground.

It is a curious fact that a careful sifting of the recorded observations discovers no unmarked warbler belonging properly to the high feeding beats. A few, such as Vermivora celata, occur at variable heights and may be seen in the tops of trees; but these usually nest low, upon or near the ground, and are usually assigned an intermediate feeding beat. It seems to be true on the whole that the plain "protectively colored" warblers are unrepresented in the upper strata of our deciduous forests, that they are common at the medium levels, and, as shown in the table, belong mainly in the lower stratum, that of thickets, brush areas, tangles about marshy places. Briefly put, the situation among warblers seems to be: no plain plumages seen at the highest levels. But the converse-no marked plumages at lowest levels-is not strictly true. No arbitrary line is drawn. About the same number of the marked and unmarked occupy the intermediate feeding beats and nesting sites. It seems reasonable to infer, however, from the results shown by this tabulation that 
top-patterns have decided utilitarian value to high-ranging warblers. That the value of white patterns is at a minimum for ground nesters and low feeders, seems to be as clearly demonstrated.

For those who find the arguments for the concealing functions of top-white conclusive, the table will primarily serve as evidence of the correctness of Mr. Thayer's interpretation. And such they are in so far as they corroborate the view that birds often seen against open foliage with sky-illuminated spaces should have and do have bright patches imitating these spaces. There may be no opposing view that can rob this one of its convincing power once it has been perceived. There is, however, a further consideration deserving attention.

High and open foliages involve more than a broken sky and leaf background with the need for imitating them. They involve wider spaces to travel; the ability to see companions at a greater distance; the need of seeing and keeping track of them by other means than call-notes; the long continued habit of so doing.

The warblers are among the most mutually dependent of birds, the least solitary, migrating in flocks and social during the daytime-portions of their travel. Among the least social the shyest and most retiring of the family are the plain or somberhued species, including the so-called water thrushes (Seiurus noveboracensis and S. motacilla) and the Connecticut and mourning warblers (Oporornis agilis and $O$. philadelphia). The bolder, the most familiar, are in the Dendroica group (Dendroica coronata, maculosa, auduboni, etc.). This need not be a mere coincidence. We have noticed the same tendency in the order at large. With a preference for close, leafy coverts and secluded forest ways go the somberer tones, the monochrome coloration, and shy, furtive habits. With a preference for open woods and roving ways, greater distances and separations to be adjusted, have come the greatest variety of top-patterns among birds, many of them showing excellent devices for a revealing flight from the opening wing. 


\section{SEXUAL SELECTION AS AFFECTING WHITE PAT- TERNS.}

It remains for us to touch on the question, does sexual selection enter into the problem of white patterns? For open-ground birds we can promptly answer that it does not. There are, however, many instances among arboreal birds where the white marking is intensified in the male. This very fact militates against the physiological contention that greater vigor in the male sex accounts for all color differences. White blotches or bars are caused by the absence of pigment. Were it not for the more intense coloration of other parts we might conclude on this basis that the white-marked male is deficient in vigor. It also argues against the view that white patches afford the best possible concealing pattern, for in that case the female should not have them obscured. Adherents of the directive theory may find support for their views in the fact that white wing bars do actually persist in the female in many cases, as in the pine grosbeak (Pinicola enucleator) and the whitewinged crossbill (Loxia leocoptera) and others, so that it eannot be regarded as due solely to sexual selection. The analogy in the case of open-ground birds where both sexes are alike, as a rule, strengthens the directive interpretation. Further, if we are right in assuming that the male is the more vigorous and the leader of bird movements, then there is ground for believing that white markings, even though intensified in the male, are directive in some sense. That such a relation exists among warblers was the belief of Dr. Coues when he wrote the following paragraph descriptive of the warbler family.

"Some travel true to the meridian in hours of darkness, stopping at daybreak from their lofty flights to rest and recruit for the next stage of the journey. Others pass more leisurely from tree to tree in a ceaseless tide of migration, gleaning as they go. The hardier males in full song and plumage lead the way for the weaker females and yearlings." 


\section{DIRECTIVE MARKINGS OUTSIDE THE ORDER PASSERIFORMES.}

An instance of revealing coloration outside the order Passeriformes seems worth citing since the very existence of a principle of directive coloration has been questioned (Thayer, 1900). The wings of the nighthawks, both eastern and western species, are, as is well known, marked with a single white spot in each. Far from tending to merge the bird's contour with anything in the background, these spots easily reveal and characterize the bird to observers. Even were there need for the nighthawks in their swift, crepuscular flights to be hidden from winged pursuers, it is hardly credible that the spots should serve this purpose. The Texas nighthawk (Chordeiles acutipennis texensis) is known to have a habit which gives revealing effect to the white throat-patch, as well as that on the wing. This throat patch is concealed as the bird takes its daytime rest in the open; but when surprised upon its nest it adopts the familiar wounded bird tacties to divert attention. After fluttering a short distance it faces the intruder, elevates and depresses its breast, thus appearing to make every effort to hold the attention of its enemy. Such a motion adds decidedly to the conspicuousness of the white patch. This effect of a pattern and corresponding behavior of the bird is perhaps unique, but it seems at least to establish a case of the revealing function of white.

\section{CONCLUSION.}

This paper has attempted to test the validity of the older interpretation of white markings in birds by analyzing their mode of occurrence in a single order, and to harmonize it, if valid, with a newer and apparently contradictory interpretation. It has shown that there is good ground for believing that flightexposed markings, whatever their mode of evolution, are of actual utility to birds as sight-clues, whether occurring in the comparatively uniform rear markings of the open ground species, or the varied top patterns of the arboreal. It has called attention to a decided correlation of the markings with the habit of 
flocking, as well as with that of open ranging. It has shown that sexual selection can only have operated in producing a more sharply defined pattern in the male, but cannot account for the existence of the pattern itself. Recent views as exemplified in Thayer (1909) as to the concealing effect of white markings have been regarded as greatly simplifying the problem and aiding our understanding of the possible meaning of the patterns. This newer view, however, is found to be in perfect accord with the older one known as the Theory of Directive Markings. It restricts the application of the latter, however, to patterns that can be shown to be conspicuous.

These considerations cannot be regarded as affording evidence in an ultimate sense. They lead at best to the provisional modification of an interpretation that was open to criticism, and tend to check over-emphasis upon the concealing principle in animal coloration. Doubtless they fall short of reaching the full meaning of the white or bright patterns of passeriform birds. Possibly the interpretation of diverse coloration as having developed under conditions of comparative immunity, from such sources of attack as those to which terrestrial animals are subject needs greater emphasis than has been given it. 


\section{LITERATURE CITED.}

Bailey, F. IM.

1902. Handbook of birds of the western United States. Boston, - 1902 ; 8vo., pp. 1-512, 33 pls. and 601 text figures.

Chapman, F. M.

1907. The warblers of North America. New York, 1907; 8vo., pp. i-viii, 1-306, 24 pls., 12 half-tone pls.

Coues, E.

1903. Key to North American Birds. Boston, 1903; roy. 8vo., pp. i-xli, $1-1152$, v. 1 and 2,3 pls., 747 text figures.

\section{Cunningham, J.}

1900. Sexual dimorphism in the animal kingdom. London, 1900; 8vo., pp. i-xi, 1-317.

Jones, L.

1900. Songs of the warblers. Oberlin College Lab. Bull. no. 10, pp. $1-56$.

Marshall, G., and Poulton, E. B.

1902. Five years' observations and experiments on the Bionomies of South African insects; chiefly directed to the investigation of mimiery and warning coloration. Trans. Entom. Soc. London, 1902, pp. 287-541, 23 pls.

Piepers, M. C.

I907. Noch einmal Mimicry, Selection, Darwinismus, Leiden, 1907, 8vo., pp. 1-481.

Poulton, E. B.

1890. The colors of animals. London, 1890,8 vo., pp. i- $x \mathrm{v}, 1-360,1 \mathrm{pl}$, 66 text figures.

\section{Riddle, $\mathbf{0}$.}

1908. The genesis of fault bars and the cause of alternating light and dark fundamental bars. Biol. Bull., v. 14, no. 6, pp. 327370,4 pls., 5 text figures.

\section{Reighard, J.}

1908. An experimental field study of warning eoloration in Coral Reef Fishes. Washington, D. C., Carnegie Inst. Papers from Tortugas Lab., pp. 261-331, 5 pls. 
312 University of California Publications in Zoology. [VoL. 6

\section{Thayer, A. H.}

1900. Arguments against the banner-mark theory. Auk, v. 17, pp. 108113.

1909. An arraignment of the theories of mimicry and warning coloration. Pop. Sei. Monthly, v. 75, pp. 550-570, 12 figures.

\section{Thayer, G. H.}

1909. Concealing coloration in the animal kingdom, with preface by A. H. Thayer. New York, 1909, 4to, pp. i-xx, 1n260, 16 colored pls., and 140 text figures.

Todd, J. E.

1888. Directive colors in animals. Am. Nat., v. 22, pp. 201-207.

Wallace, A. R.

1889. Darwinism. London \& N. Y., 1889, 8vo., pp. i-xvi, frontispiece, map, 37 text figures. 
Vol. 8 , I. Some Observations on the Nervous ststem of Copppodas by 0.0 . Fsterly. Pp, 1-12, plates 1-2. Jamuary, 1906.

2. (IX) * Ostracoda of the San Diego Lieglon. 1. Talocypriaae, by Ohancey Juday. PD. 13-38, plates 3-7. Apri, 1906.

8. (x) The daliformia Shore Anemone, Bunodactis xanthogrammica, by Hany Beal Torrey. Pp, 41-46, plate 8, April, 1906.

4. (xa) Sesual Dimorphism in Aglaaphenia, by riarty Beal Horres and Ani Maring. Po. $47.52,9$ texth-figures. Aprit, 1906.

Nos, 8 and 4 in one cover

5. (XII) New Copepod Fauna from the San Diego Region, by Calvin Olin Esterly. Pp. 53-92, plates 9-14. December, 1906.

6. (XII) Dinotiagellata of the San Diego Region, II. On Triposolenia a Now Genus of tho Dinophysidae, by Oharles Atwood Kofoid. IP. 93-116, plates 16-17.

2. A Discussion of the Species Characters in Iriposolenia. I. The Nature of Species Characters. II. The Adaptive Significance of Species Characters, IIt. The Coincident Distribution of Related Species. By Charles Atwood Kofold. Pp. 117-126.

8. On the Significance of the Asymmetry in Triposolonis by Charles Atwood Kafoid. Pp. 127139 .

Nos. 6, 7, alua 8 in one cover. December, 1906.

9. (XIV) Ostracoda of the San Diego Region. II. Iittoral Forms, by Chancey Juday. Pp. 135-156, plates 18-20.

10. (XV) Cladocera of the Sam Diego Region, by Chancey Juday. P. $157-158,1$ test figure.

Nos. 9 and 10 in ono cover. Jamiary, 1907.

11. (XVI) The Marine Fishes of Southern Califomia, by Fdwin Chaplin Starlis and Farl Loonaxd Morris. Pp. 159-251, plate 21. March, 1907.

12. Biological Studies on Corymorpaa. II. Iho Development of C. Palma lrom the Fgs. I8y Harry Beal Irorgy. Pp. 253-298, 38 test figures. Jume, 1907

1S. (XVII) Binoflagellata of the San Diego Region. II. Descriptions of Jew Species. By Charles Atwood Fofold. Pp. 299-340, plates 22-28, April, 1907

14. The Structure and Movements of Condylostoma patens, by John $F$. Bovard. Pp. 913-368, 21 text igurea Sentember, 1907 Inder, pp, $369-\$ 83$.

Fol. I. 1, the Asclatans collected by the United States Itsheries Bureau steamer Albatross on the coast of California daring the simmer of 1904 , by William Fmersón Ritter. Pp. 1-52, plates 1-3. October, 1907 . XVII) Behavior of the Etarfish Astaxias forreri de fornicl, by $\mathbf{1}$. 8 . Jennings. Ro. 58-185, 19 test figures. November, 1907.

3. (XoX) The Barly Life-History of Dolichoglossus pusthus Bitter, by $\mathbf{B}$. II. Dápis, Pp. 187-226, plates 4-8. March, 1908

4. Notes on two Amphivods of the Genus corophinm from the Pacife Coast, by J. Ohester Bradley. Pp. 227-252, plates 9-13. Apri, 1908.

5. (XX) The Incruating dhilostamatous Bryozoa of the Westerm doast of North America, by Alice iobertson. Pp. 258-344, plates 14-24, May, 1908 (1)

6. (XXI) On Exuviation, Ajtotomy, and Begeneration in Ceratium, by Charles Atwood Kofoid. Pp. 345-386, with tert figures.

7. (XXII) Notes on some Obscure Species of Ceratium, by Charles Atwood Kofold. Pp. 387-393.

Nos, 6 gad 7 in one coven. April, 1908. ....................... Tndex, pp. $395-400$.

7ol. 6. 2. The Biota of the san Bernardino Mountains, by Joseph Grinnell. Py.

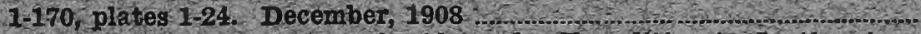

2. Birds and Mammals of the 1907 Alexander Expedition to Southeasterp Alaska. Pp. 171-264, pls, 25-26, figs, 1-4, Lebruary, 1909 ,

3. Whree New Song Sparrows trom California, by Toseph Grinnell. Pa. 265-269. April 9, 1909

1. A New Harvest Mouso from Petalima, California, by Joseph Diron.

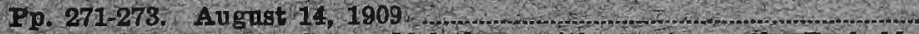

5. A New Cowbird of the Genus Molothrus, with a note on the Probable Cenetic Relationships of the North American Forms, bs Joseph Grinuell Pp. 275-281, 1 text figure, December, 1909.

6. Lwo New Rodents from Nevada, by Waiter P. Laylor. Pp, 283-302, plates $27-29$. 3.5

7. A Northem Coast 1 orm of the Oalifornia Gray 10x, by Joseph Diron. Pp. 308305 .

Fey. 6 and 7 in ond cover February, 1910. 
8. Iwo fietetorore Unnamed Wreins of the Cenus Thryomanes, by Tosephi Grinnell. Tp, 307-309.

9. The Savannah Sparrow of the Great Bain, by Josoph Girmall. Pp. 311-316.

10. A Second Record of the spotted Bat (Bruderma maculatum) $10 \mathrm{x}$ California, by Joseph crinnell, Pp. $317-320$, plate 30.

Nos. 8, 9, and 10 in one cover. Tebruary, 1910

11. Wammals of the 1908 Merander Alaska Eapedition, with Desciption: of the Locallities Visited and Notes on the Plora of the Prince Wiliam Sound Region, by Bdmand Hellex. Pp, 321-360, plates 81-32.

12. Birds of the 1908 Alexander Alaska Bxpedition, with a Tote on the A vifaumal Relationships of the Prince William Souna District, by Joseph Grimell. P0. 361-428, plates 38-34, 9 test-figures.

Tros, 11 and 12 in one core. March, 1910 Inder, pp. 429-440.

V01. 6. 1. (xxmI) On the Weight of Developing Izgs. Part $t$, the pordblo

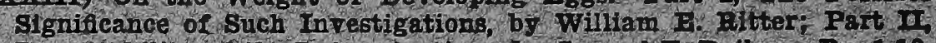
Evarcticaloility of the Dowermination, by Samuel E-Bafley $P$. $1-10$. October, 1908

2. (XXV) Tho Ieptomedusae or tho San Diego Region, by Hary Beal Torkey. Pp. 11-31, with text figures. February, 1909

S. (XXV) The Ophivians of the San Diege Degion, by o. If Mcclendon Pp. 83-64, plates 1-6. July, 1909

4. (XXVI) Hatocynthio johnsomi n. BD. A comprehenstro linquiry as to the extent of low and order that prevalls in a single animal spectes by Wm. E. Bitter. Pp. 65-114, plates 7-14. Tovember, 1909.,...

5. (XXVII) Three species of Cerianthus from Southern Califomia, by

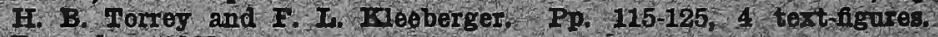
Decomber, 1909

6. The tife Iistomy of Trypanosoma Dimorphon, Datton \& Hodd by Fdward Ithdie. Pp, 127144, plates 15-17, 1 tert-figure December, 1909

7. (XXVII) A Quantitative Study of the Develogment of the salpa Chain in Salpa fusiformis-rumbinata, by Miytile FHizabeth Johnsone. Pp. 145176. March, 1910

8. A Revision of the Genús deratocorys, Based en Skoletal Motehologr. by Charles Atwood krofoia Pp 177-187. May, 1910

9. (X)IX) Ireliminary Report on the Iydrographic Wort Carried on by the Marine Biological Station of San Diego, by George I. Nictwen. P0. 189-204, text-figure and map. May, 1910

10. $(\mathbf{X} \times \mathbf{X})$ Bioligical Studies on Cortmorpha. III. Regeneration of HFdiranth and Holdfast, by Fary Beal Tomer. Pp. 205221; 18 tertfigures:

11. (XXXI) Tote on Geotropism in Corymorpha, by Hanty peal Ioprey. P0. 223-224; 1 text-figrire.

2Tos. 10 and 11 in 0 ae cover. Angust, 1910

12. The Cyclostematous Bryozoa of the West Coast of Worth America by Allice Robertson, Py. 225-284; plates 18-25. December, 1910

18. Significance of White Marloings in Birds of the Order Passeriformes, by Heny Chester Thacy. Pp. 285-312. December, 1910 .

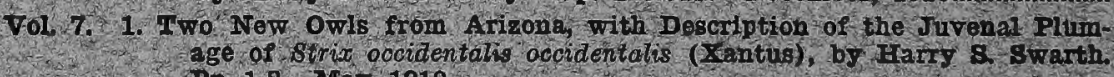
Pp. 1-8. May, 1910 .........

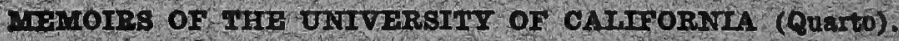

Vol. 1. 25o. 1. Iriassic Ichthyosauris with ppecial teference to tho American Forms. BX John C. Morrizm. Pages 1-196, plates 1-18, 164 tast ilzures september, 1908

Vot. 2. The Silva of California, by Willis Linn Jepson. 480 pagos 85 plates, 3 maps, December, 1910

… 6.50

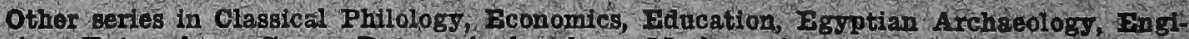
neering, Entomology, Graceo-Roman Archaology, Mathematics, Psychology, Semitic Phil. ology, Modern Phitology

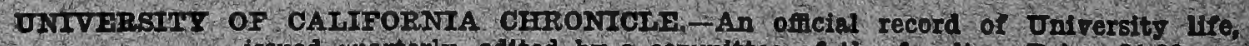
issued quarterly, edited by 8 committeo of the troulh. Price $11.00 \mathrm{pet}$ tear. Current tolinie $\mathrm{N}$. $\mathrm{XIII}$.

Addrabs all orders; of requests for information concerning the above publications to The Uniratalty Press, Berkeley, Calliforaia.

European agent for the series in American Archaeology and Ethnology, Chassical phil. ology, Bdacation, Modern Philologs, Philosophy, and Semitio Philologs, Otto Framaicsomits Leipzig. Ior the Memoirs, and the series in Botany, Geology, Pathology, Physiologi? Zoology and also Amorican Archaeologt and rthnology, B. Friediander 8 solh, Barlin. 

